\title{
PENGUNAAN MEDIA MOVING FLAHSCARD UNTUK STIMULASI KEMAMPUAN LITERASI ANAK USIA DINI
}

\author{
Asdi Wirman ${ }^{1}$, Yulsyofriend ${ }^{2}$, Yaswinda ${ }^{3}$ Andriana Tanjung ${ }^{4}$ \\ PG PAUD, Fakultas Ilmu Pendidikan, Universitas Negeri Padang \\ Email : asdi.wirman@yahoo.com
}

\begin{abstract}
ABSTRAK
Aspek kemampuan literasi adalah salah satu potensi anak yang mesti dikembangkan semenjak dini. Pengembangan kemampuan literasi mesti seimbang dan terintegrasi dengan lingkup perkembangan anak lainnya. Optimalisasi pengembangan kemampuan literasi menuntut kesiapan para pendidik yang mampu memberdayakan berbagai fasilitas untuk menfasilitasi perkembangan literasi, termasuk perihal media pembelajaran. Pergeseran ke era digital terkadang menjadikan pembalajaran monoton berbasis teknologi komputer. Pada hal tidak tertutup peluang bagi pendidik untuk menggunakan media yang tidak berbasis komputer. Salah satunya adalah media moving flashcard. Media ini akan menfasilitasi anak baik yang memilii gaya belajar visual, audio apalagi kinestetik. Sehingga anak bisa secara bersama-sama belajar dengan fun dan menyenangkan. Selain itu anak juga bisa berkompetisi, bekerja sama sehingga pembelajaran lebih efektif.
\end{abstract}

Kata Kunci: media moving flaschcard; literasi anak usia dini

\begin{abstract}
The aspect of literacy ability is one of the children's potential that must be developed early. The development of literacy skills must be balanced and integrated with the scope of other children's development. Optimizing the development of literacy skills requires the readiness of educators who are able to empower various facilities to facilitate the development of literacy, including about learning media. Shifting to the digital age sometimes makes monotonous learning based on computer technology. In the case of not being closed, opportunities for educators to use media that are not computer-based. One of them is flashcard moving media. This media will facilitate children who have visual, audio and kinesthetic style of learning. So that children can learn together with enjoyfull and fun. In addition, children can compete, working together so that learning is more effective.
\end{abstract}

Keywords: Moving Flashcard; Literacy of early childhood

\section{PENDAHULUAN}

Anak disaat lahir sudah membawa potensi. Potensi yang dimiliki anak beragam. Namun potensi yang dibawa itu perlu dikembangkan secara optimal. Salah satu potensi anak adalah potensi literasi. Pengembangan kemampuan literasi pada anak mesti diintegrasikan dengan pengembangan kemampuan lainnya seperti agama, sosial, pengetahuan dan keterampilan anak. Upaya ini mesti difasilitasi oleh pendidik yang mampu mengembangkan dan meningkatkan kompetensi anak baik di keluarga, di lembaga PAUD maupun di masyarakat. Namun, terdapat beberapa persoalan yang terjadi dalam konteks pengembangan kemampuan literasi anak, diantara persoalan itu adalah antara lain 
keberagaman pemahaman tentang konsep literasi, kemampuan orang tua dan bahkan pendidik dalam pengembangan literasi anak, serta pemanfaatan dan penggunaan media dalam pengembangan kemampuan literasi anak.

Orientasi pendidikan anak usia dini mesti berorientasi untuk masa depan atau futuristik. Artinya anak-anak disiapkan pada saat ini untuk mampu menghadapi masa mendatang yang memiliki berbagai tantangan. Apalagi tantangan dan tuntutan masa depan semakin kompleks. Upaya pengembangan segenap potensi yang dimiliki oleh anak mesti holistik dan integral serta konteks dengan zamannya. Tugas terberat pendidik adalah memberikan bekal bagi kesiapan anak didiknya menghadapi masa depan. Selain itu tuntutan pengembangan potensi anak secara multipel mesti terintegrasi dengan pencapaian kompetensi inti yang dimiliki anak yang meliputi aspek religius, sosial, pengetahuan dan keterampilan.

Belum lagi perkembangan kemajuan zaman dan era digital saat ini menjadikan anak sangat dekat dengan komputer dengan berbagai fasilitasnya. Hal ini tentu saja menimbulkan berbagai konsekuensi. Salah satu konsekuensinya adalah menjadikan anak sangat dekat dengan berbagai fasilitas pembelajaran berbasis komputer. Konsekuensi itu berdampak besar pada tuntutan terhadap guru untuk menggunakan fasilitas tersebut dalam dunia pembelajaran. Selanjutnya anak akan nyaman ketika pembelajaran berbasis komputer dan menjadi tidak terlalu tertarik dengan media lainnya. Persoalan selanjutnya adalah bagaimana para pendidik mampu mengembangkan kemampuan mereka dalam merancang dan menggunakan media-media selain berbasis komputer untuk mewujudkan adanya variasi media dalam pembelajaran dan hal itu juga bisa dimanfaatkan dalam pengembangan kemampuan literasi anak.

Artikel ini secara khusus membahas tentang bagaimana menggunakan media moving flashcard untuk menstimulasi kemampuan literasi anak.

\section{METODE PENELITIAN}

Metode yang digunakan dalam penulisan artikel ini adalah literature review atau kajian berbagai sumber teori terkait dengan penggunaan media moving flashcard untuk stimulasi kemampuan literasi anak usia dini, serta kajian-kajian lain yang sesuai dengan topik. moving flashcard sebagai salah satu alternatif media pembelajaran untuk stimulasi kemampuan literasi anak usia dini.

\section{Kajian Teori}

\section{Kemampuan Literasi Anak Usia Dini}

Literasi secara umum seperti yang dijelaskan oleh Pilgrim dan Martinez (2013: 1) berkenaan dengan membaca dan menulis secara efektif dalam konteks yang bervariasi, “ 
Literacy generally refers to reading and writing effectively in a variety of contexts". Namun dalam perkembangannya istilah literasi berkenaan dengan berbagai hal seperti literasi media, literasi keuangan, literasi kesehatan, literasi virtual, sekolah dan lainnya.

Untuk mampu anak mengenal berbagai literasi tersebut maka salah satu yang perlu dikembangkan kepada anak adalah kemampuan mengenal simbol termasuk dalam hal itu simbol tulisan dan juga huruf. Oleh karenanya literasi juga berkaitan dengan kata, suku kata dan huruf sebagai bagian dari kemampuan bahasa atau membaca bagi anak usia dini.

Mengkaji masalah kemampuan bahasa anak usia dini terdapat tiga aliran besar antara lain pandangan behaviorist, innatist dan interactionist. Aliran behavioris menekankan pentingnya peran pendidik baik orang tua atau orang dewasa dalam menstimulasi bahasa anak, atau faktor prilaku dalam berbahasa seperti positif reinforcment terhadap respinsif bahasa anak. Aliran innatis memiliki pandangan bahwa potensi bawaan saat lahir atau faktor genetikal merupakan hal yang sangat menentukan dan mewarisi perkembangan bahasa anak. Adapun aliran interaksionis menjelaskan bahwa lingkungan tempat anak berada dan saling berinteraksi merupakan faktor utama yang mendorong terjadinya stimulasi terhadap perkembangan bahasa anak (Essa, 2011: 360).
Berdasarkan pendangan di atas peran orang sekitar dan intensitas komukasi yang terjadi, faktor potensi fisik, dan psikis bawaan, serta lingkungan tempat berinteraksi merupakan tiga faktor utama dalam menentukan pemerolehan bahasa anak usia dini. Oleh karenanya optimalisasi peran orang sekitar dalam stimulasi kemampuan literasi anak sangat dibutuhkan, termasuk dalam hal ini pendidik di lembaga pendidikan anak usia dini.

Berkenaan dengan penjelasan di atas Essa (2011: 375) mengemukakan bahwa perkembangan bahasa anak usia dini menuju menulis dan membaca dari words menjadi literate merupakan proses yang dinamis dan berkelanjutan serta emergensi dalam peningkatan kemampuan literasi anak. Pendapat ini semakin menguatkan bahwa stimulasi kemampuan literasi anak semenjak usia dini sangat menentukan kemampuan literasi anak pada usia selanjutnya. Apalagi literasi dipahami bukan saja masalah kemampuan melek huruf dan keaksaraan tetapi merupakan kemampuan dasar manusia untuk memahami, menganalisis dan mengolah informasi dalam hidup dan untuk kehidupan.

\section{Media Moving Flashcard}

Moving flashcard merupakan salah satu media yang dapat digunakan dalam berbagai kegiatan pembelajaran, termasuk untuk pembelajaran literasi. Sebelum menjelaskan tentang media 
moving flashcard terlebih dahulu dijelaskan tentang konsep media.

Di antara pakar yang menjelaskan media antara lain Heinich (1996: 10) mendefinisikan media sebagai sesuatu yang dapat membawa informasi dari sumber kepada sang penerima pesan yang bertujuan untuk menfasilitasi komunikasi. Miarso (2004) juga menjelaskan bahwa media yaitu segala sesuatu yang digunakan untuk menyalurkan pesan dan dapat merangsang pikiran, perasaan, perhatian, dan kemauan si pebelajar sehingga dapat mendorong terjadinya proses belajar. Sementara itu Pribadi (2010: 46) mengemukakan definisi bahwa media adalah sarana pembelajaran yang dapat digunakan untuk menfasilitasi aktivitas belajar atau "perantara" yang menghubungkan antara guru atau instruktur dengan siswa dalam proses pembelajaran yang efektif, efisien dan menarik.

Heinich

(1996:10)

mengilustrasikan variasi media pembelajaran antara lain: nonprojected media, projected media, audio media, motion media, computer mediated instruction, computer based multimedia and hypermedia dan media for distance learning. Variasi media yang dikemukakan tersebut akan memberi efek makna pesan sesuai dengan tingkat pengalaman yang akan dicapai. Oleh karenanya Dale dalam Kerucut Pengalaman yang dikemukakan mempertegas bahwa situasi real atau total situation menjadikan pembelajaran itu kongret pada anak (Heinich, 1996: 16).

Pannen, dkk (2003: 8) mengemukakan beberapa manfaat media pembelajaran antara lain: siswa sukses belajar dengan pengalaman nyata, proses pembelajaran kondusif, efektif, efisien, kemampuan siswa dapat ditingkatkan, siswa mandiri dan belajar aktif, dan dapat memberi perbaikan pada metode pembelajaran. Di antara implementasi media dengan metode pembelajaran terlihat nyata pada komponen yang terdapat dalam metode antara lain: presentasi, demonstrasi, diskusi, tugas dan latihan, tutorial, belajar kelompok, permainan, simulasi, discovery, dan problem solving.

Walaupun perkembangan media sangat pesat namun setiap media memiliki kelebihan dan kekurangan. Tidak mesti di era digital penggunaan media serba digital karena psikologis media dan kemampuannya mengantar pesan antara satu media dengan lainnya juga berbeda. Apalagi bagi daerahdaerah yang akses internet masih terbatas dan termasuk ketersediaan sarana pendukung di sekolah masih minim maka dituntut kreativitas guru untuk mampu mendesain dan menciptakan media-media inovatif dan efektif. Salah satu media yang sangat mudah dibuat adalah flashcard.

Pengertian media flashcard dikemukakan oleh beberapa pemikir dan juga sekaligus praktisi, antara lain; Suyanto menjelaskan bahwa flashcard adalah media pembelajaran dengan 
kartu bergambar dengan ukuran tertentu. Adapun kartu bergambarnya bisa dibuat sendiri atau menggunakan foto dan gambar dengan cara menempelkannya. Selain Suyanto, Arysad (2011: 119) juga menjelaskan bahwa flascard merupakan media kartu yang berisi gambar, teks, simbol yang mengingatkan atau mengarahkan anak kepada sesuatu yang berhubungan dengan gambar. Bahkan Indriana (2011) menjelaskan bahwa flashcard adalah media pembelajaran yang berbentuk kartu bergambar seukuran postcard atau sekitar 25 x 30 CM.

Susilana dan Cepiriyana (2012: 95) menjelaskan bahwa flashcard karena memiliki dua sisi maka pendidik bisa memanfaatkan kedua sisinya. Media flashcard memiliki kelebihan karena sederhana, mudah dibawa, juga bisa dimodifikasi.

\section{HASIL DAN PEMBAHASAN}

\section{Penggunaan Media Moving Flaschcad dalam Stimulasi Kemampuan Literasi Anak Usia Dini}

Memahami perkembangan anak merupakan salah satu kompetensi yang mesti dimiliki oleh pendidik. Begitu juga halnya pada saat pendidik akan mengembangkan kemampuan literasi anak maka mereka mesti mengerti tentang berbagai karakteristik anak. Pakar pendidikan anak usia dini Kellough (1996) mengemukakan bahwa karakteristik anak usia dini antara lain bersifat egosentris, memiliki rasa ingin tahu yang besar, makhluk sosial, bersifat unik, anak umumnya kaya dengan fantasi, anak memiliki daya konsentrasi yang pendek, dan anak merupakan masa belajar yang paling potensial.

Pemahaman

tentang karakteristik perkembangan anak mesti dijadikan dasar dalam merencanakan dan melaksanakan kegiatan pembelajaran pada anak usia dini. Namun permasalahan tiodak sesederhana itu ternyata ada masalah lain yang terjadi di lapangan. Permasalahan itu terjadi dalam pembelajaran literasi pada anak usia dini.

Terdapat beberapa persoalan dalam pembelajaran literasi pada lembaga PAUD berdasarkan pengamatan dan diskusi dengan praktisi berdasarkan pengalaman selama ini antara lain terminologi literasi anak usia dini dipahami guru secara sempit. Umumnya guru pada lembaga PAUD apalagi pamong memahami bahwa literasi adalah kemampuan membaca dan menulis anak. Hal ini berefek pada learning outcome proses pembelajaran di PAUD pada umumnya berorietasi pada anak pandai membaca dan menulis.

Pada hal literasi dipahami bukan hanya sekedar melek huruf dan keaksaraan. Namun, literasi merambah kepada kemampuan dalam melek informasi melalui berbagai simbol yang terdapat dalam lingkungan kehidupan sehingga mampu memecahkan masalah- 
masalah sederhana sendiri, mempelajari informasi sendiri, bahkan mampu menimba dan memahami informasi dari berbagai sumber. Pengembangan kemampuan literasi seperti ini mesti dilakukan sedini mungkin.

Selain persoalan pemahaman tentang apa itu literasi hal lain yang penting adalah bagaimana mengembangkan kemampuan literasi. Apabila dirujuk pernyataan International Reading Association (IRA) 2005 seperti yang dikutip Essa (2011: 374) terdapat 5 fase pengembangan kemampuan literasi yaitu fase 1 infan (kesadaran dan eksplorasi), fase 2 kindergarten (membaca dan menulis eksperimental), fase 3 membaca dan menulis awal (grade 1), fase 4 (membaca dan menulis transisi (grade 2), serta fase 5 membaca dan menulis independen dan produktif (grade 3).

Fase serta grade kemampuan anak berdasarkan perkembangan bahasa dan literasi anak di atas semakin mempertegas bahwa guru dan pamong anak usia dini mesti memahami dengan baik salah satunya fase perkembangan literasi anak dalam upaya pengembangan kemampuan literasi mereka. Bahkan Essa (2011: 375) mengutip beberapa element esensial dalam literasi menurut Halle, Calkins, Berry, \& Johnson (2003), Rascos, Christie, \& Richgels (2003) antara lain: khazanah pembicaraan guru (percakapan, kosa kata baru, variasi topik dan kesungguhan respon serta respek anak secara total), kegiatan membaca, kesadaran phonologis, pemahaman tentang abjad atau huruf, kesadaran dalam mensupport kemampuan membaca dan pengembangan kemampuan menulis dini.

Terdapat beberapa saran dari berbagai sumber untuk pengembangan literasi anak yang dikutip oleh Essa (2011: 381-382) antara lain: NAEYC \& IRA (2005) yang menekankan bahwa tujuan pengembangan kemampuan literasi anak usia dini adalah untuk memperkaya hal yang dapat memicu motivasi instrinksik dalam meningkatkan skill membaca dan menulis. Adapun Machado (2009) menekankan pentingnya variasi aktivitas, materi, dan perencanaan dan spontanitas dalam interaksi oral dan menulis.

Dampak dari mis-pemahaman pendidik tentang terminologi literasi berkaitan pada learning outcome, persiapan materi, metode yang dipilih dan asesmen yang digunakan dalam mengidentifikasi capaian anak.

Penjelasan di atas semakin mempertegas tentang pentingnya upgrade ilmu pengetahuan dan pemahaman bagi pendidik literasi khususnya tentang pengembangan literasi anak usia dini. Hal ini dapat dilakukan dengan memperkaya wawasan dari berbagai literatur serta mengikuti seminar dan pelatihan berkenaan literasi anak usia dini. Brewer (2007: 304) menjelaskan IRA (2003) berupaya mengidentifikasi 
standar kualitas pendidik yang akan mengembangkan kemampuan literasi anak usia dini. Terdapat 5 standar pendidik literasi menurut IRA (2004) antara lain 1) memiliki pengetahuan tentang dasar proses membaca dan menulis serta proses pembelajarannya, 2) memberi porsi besar pada ranah praktek, pendekatan, metode, dan materi kurikulum untuk mendukung proses pembelajaran membaca dan menulis, 3) menggunakan perangkat asesment yang variatif dan variasi penerapan perencanaan dan evaluasi efektif dalam proses pembelajaran membaca, 4) menciptakan lingkungan literasi yang membentuk membaca dan menulis dengan mengintegrasikan dasar pengetahuan, praktek, pendekatan, metode, materi kurikulum dan asesmen yang cocok, dan 5) memiliki pandangan pengembangan profesi sebagai karir dan tanggung jawab (Brewer, 2007: 309).

Selain faktor pemahaman guru dan pamong anak usia dini tentang kemampuan literasi anak, hal lain yang juga sangat penting adalah permasalahan media pembelajaran yang mendukung proses pembelajaran. Ada beberapa tahapan kegiatan penggunaan media moving flashcard dalam kegiatan stimulasi kemampuan literasi anak usia dini antara lain:

1. Guru dapat melibatkan anak untuk membuat media flashcard

Sebelum membuat media tentu saja guru menyiapkan semua peralatan yang dibutuhkan dan material yang digunakan. Kemudian guru dapat melibatkan anak secara bersama-sama sehingga akan terbangun jiwa kerja kelompok, kepedulian, saling membantu, dan juga jiwa kepemimpinan.

Guru dapat memperlihatkan media yang sudah siap untuk dipakai untuk menumbuhkan motivasi anak dalam mengerjakan pekerjaan kelompok mereka. Bahkan kegiatan kerja kelompok dapat dilakukan guru setelah selesaikegiatan pembelajaran dilaksanakan.

2. Tahapan penggunaan media moving flashcard

Media flashcard dapat berupa gambar buatan sendiri dengan tiga dimensi seperti gambar ikan yang dibuat dari potongan kertas karton manila dan dari bahan lainnya. Selanjutnya gambar ikan tersebut dapat diperlihatkan kepada anak dengan cara membuat tempat menempelkannya. Setelah diperlihatkan anak akan langsung merespon itu ikan. Selanjutnya guru dapat menempelkan huruf dengan membetuk tulisan ikan di bawah gambar ikan tersebut. Kemudian guru dapat menstimulasi anak untuk membaca gambar dengan mengarahkan telunjuk pada gambar ikan. Setelah itu guru dapat meminta anak mencari huruf pada kotak yang mirip dengan tulisan ikan tersebut.

Kegiatan selanjutnya dapat dilakukan guru dengan cara membuat tulisan ikan dengan memisahkannya menjadi dua suku kata yaitu i-kan. Fase ini juga bisa dkembangkan dengan 
menyebut binatang atau hewan lain yang juga berawalan "i" seperti i-tik dan lainnya. Anak juga bisa selanjutnya diminta mencari huruf "i” saja. Bahkan juga dapat memintanya untuk menrukan cara penulisan huruf dengan cara menyediakan kertas dengan adanya titik-titik yang bisa dihubungkan untuk membuat huruf "i".

Dua tahapan di atas dapat dilakukan dengan menggunakan dua gambar. Gambar pertama ikan dengan ada tulisan huruf ikan di bawahnya. Sedangkan gambar yang satu lagi adalah gambar ikan dengan ada tulisan dengan suku kata "i" dan "kan". Gambar yang pertama dipindahkan selanjutnya digantikan dengan gambar yang kedua.

Gambar yang terakhir adalah gambar ikan dengan adanya tulisan huruf i-k-a-n secara terpisah. Tiga gambar ini bisa dipindahkan makanya kemudian disebut dengan moving. Artinya gambar dapat dipakai secara bergantian. Kegiatan anak mencari huruf yang mirip dengan gambar pada akhirnya akan sangat singkron dengan gambar yang ketiga. Pada akhirnya anak dapat diminta untuk menyusun huruf tersebut menjadi kata ikan.

Fase kegiatan di atas memberikan pemahaman berdasarkan karateristik anak usia dini bahwa mereka masih pada taraf beripikir praoperasional kongrit. Oleh karenanya gambar ikan akan membantu mereka membaca tulisan ikan. Dan selanjutnya tulisan ikan akan diurai menjadi suku kata dan huruf-huruf yang membentuk tulisan ikan. Maka selanjutnya dari pengalaman kongrit tersebut anak akan beralih kepada kegiatan ke arah yang sangat abstrak. Namun pengalaman awal akan membantu anak. Kegiatan ini tidak boleh dipaksakan kepada anak.

Selanjutnya media flaschcard dapat diganti dengan berbagai gambar lain, apakah anggota tubuh, keluarga, tumbuhan, hewan dan lainnya. Pada intinya media moving flashcard dapat digunakan dalam berbagai tema. Hal itu merupakan bagian untuk meningkatkan kemampuan literasi anak untuk melek kepada simbol huruf berdasarkan media gambar.

\section{SIMPULAN}

Media moving flashcard merupakan media nonprojector yang dapat divariasikan penggunaannya bahkan dalam pembuatannya juga bisa melibatkan anak. Media ini dapat membantu anak yang memiliki gaya belajar visual, audio bahkan kinestetik. Karena dalam kegiatan moving media flashcard anak dapat dilibatkan dalam kegiatan yang variatif.

\section{DAFTAR PUSTAKA}

Arsyad, Azhar. 2011. Media Pembelajaran, Jakarta: Rajawali Press

Brewer. Jo Ann. 2007. Early Childhood Education. Preschool throught Primary Grades. Sixt Edition. USA: Pearson Education, Inc 
Asdi Wirman, Yulsyofriend, Yaswinda, Andriana Tanjung. PENGUNAAN MEDIA MOVING FLAHSCARD UNTUK STIMULASI KEMAMPUAN LITERASI ANAK USIA DINI . Early Childhood Vol. 2 No. 2b, November 2018

Essa. Eva. L.2011. Introduction to Early Childhood Education. 6th Edition. Canada: Nelson Education, Ltd

Heinich. $\quad$ Robert. Dkk. 1996. Instructional Media and Technologies for Learning. 5th Edition. USA: PrenticeHall, Inc https://www.researchgate.ne t/publication/288246131_D efining_literacy in the $21 \mathrm{~s}$ t_century_A_guide to term inology_and_skills (diakses 24 September 2018)

Kellough, Richard D. 1996 Understanding Children $s$ Art. New York: Macmillan Publishing Company.

Miarso. YusufHadi. 2003. Menyikapi Tabir Kebenar Ilmiah. Seminar Nasional Teknologi Pembelajaran Yogyakarta 22-23 Agustus 2003

Pannen, Pauline. Benny. A. Pribadi. Kusnadi. 2003. Media dan teknologi Pembelajaran di Perguruan Tinggi. Seminar Nasional Teknologi Pembelajaran Yogyakarta 22-23 Agustus 2003

Pribadi. Benny. A. 2010. Langkah Penting Merancang Kegiatan Pembelajaran yang efektif dan Berkualitas. Model Desain Sistem Pembelajaran. Jakarta: PT. Dian Rakyat
Susilana, Rudi dan Cepiriyana. 2012. Media Pembelajaran, Ciputat: Gaung Persada Press group

Yamin. Martinis. dan Jamilah Sabri Sanan. 2012. Panduan PAUD Pendidikan Anak Usia Dini. Ciputat: Gaung Persada Press group 